Article

\title{
Déjà Vu: Shirley Kaufman's Poetry on Biblical Women
}

\author{
Anat Koplowitz-Breier \\ Comparative Literature Department, Bar Ilan University, Ramat Gan 5290002, Israel; \\ Anat.Koplowitz-Breier@biu.ac.il
}

Received: 24 June 2019; Accepted: 18 August 2019; Published: 21 August 2019

check for updates

\begin{abstract}
This article explores Shirley Kaufman's reading of the Bible as an elaboration on/of its feminine characters via three devices: (a) Dramatic monologues, in which the woman speaks for herself ("Rebecca" and "Leah"); (b) description of specific scenes that gives us a glimpse into the character's point of view ("His Wife", "Michal", "Abishag", "The Wife of Moses", "Yael", and "Job's Wife"); and (c) interweaving of the biblical context into contemporary reality ("Déjà Vu" and "The Death of Rachel"). Fleshing these figures out, Kaufman portrays the biblical women through contemporary lenses as a way of "coming to terms with the past" and the historical exclusion of "women's bodies" from Jewish tradition, thereby giving them a voice and "afterlife". Her treatment of the biblical texts can thus be viewed as belonging to the new midrashic-poetry tradition by Jewish-American women that has emerged as part of the Jewish feminist wave. Herein, Kaufman follows Adrienne Rich and Alicia Ostriker's "re-visioning" of the Bible and in particularly its women, empowering them by making use of her/their own words.
\end{abstract}

Keywords: Shirley Kaufman; Hebrew Bible; midrash; biblical women; American Jewish poets

\section{Introduction}

In her article "Roots in the Air," American-Israeli poet Shirley Kaufman (1923-2016) observes:

I think in a sense all art is a coming to terms with the past. The literary imagination feeds on many sources. What do we do with history and mythic memory? With our western literary heritage? With our eastern literary heritage? ... How do we respond to the post-modern rupture of "certainties"? What do we do with the Bible as literature? (Kaufman 1998, pp. 162-63)

Reading Kaufman's poetry reveals that in "coming to terms with the past" she frequently means "coming to terms with the Bible." Between the publication of her first book The Floor Keeps Turning in 1970 and 2001, she published numerous poems about biblical women (Lot's wife, Sarah, Hagar, Rebecca, Leah, Rachel, Zipporah, Yael, Michal, and Abishag), explaining that she was "looking back at the women in the Bible who keep getting into my poems" (Kaufman 1997, p. 220). Poetry influenced by the Bible is an integral part of Jewish writing in general and modern Hebrew poetry in particular. In the introduction to The Defiant Muse: Hebrew Feminist Poems from Antiquity to the Present: A Bilingual Anthology, she and her co-editors noted:

Biblical mothers nurture the muse of many modern poets. ... Biblical and postbiblical traditional Jewish texts remain the bedrock of Hebrew poetry. Women poets derive their own vocabulary from this foundation, though no longer from a disadvantaged position ... [Herein, they] cultivate a complex and fruitful relationship with traditional Hebrew texts, akin to the developments Alicia Suskin Ostriker has described as "revisionist mythmaking" in her influential study of women's poetry in America (Kaufman et al. 1999, p. 15) 
Such use of the Bible by women (and men) Hebrew poets formed part of Zionist ethos, which championed a return to the Hebrew language and the Bible as a cultural source. As Gershon Shaked remarks in this regard: "Hebrew literature ... needed the canonical text, and by means of it attempted to give the present legitimacy derived from the past and to lay out a path to a national future" (Shaked 2004, p. 47). This tendency towards returning to the Bible and reading it anew was also a characteristic of the American-Jewish feminist movement. Examining "Poetry, Midrash, and Feminism," Steven Schneider thus remarks:

[One] of the most interesting currents in contemporary Jewish American poetry [is] the use of poems to create commentaries on the Jewish Bible. This impulse, which I shall call midrashic, is especially strong in the work of contemporary Jewish women poets, who strive to give voice to biblical figures, especially women, whose stories have either been muted in the Bible or who often are represented as flawed, deceitful, or simply a liability. As a mode of writing, postmodern Jewish American poetry by women delights in creating "midrashic commentaries" as a strategy to counter this silence, to challenge the perception of women as inferior, to strengthen Jewish female identity, and to register political and social concerns. (Schneider 2001, p. 61)

Although a longtime Israeli resident (1973-2011) who translated Hebrew poetry into English, Kaufman never fully mastered spoken Hebrew. In fact, she always regarded herself as a type of hybrid:

Perhaps the best word to describe my condition is hyphenated, American hyphen Israeli, a title by which I am frequently introduced. When I look at this hyphen-the little horizontal line between American and Israeli that substitutes for "and" or "and/or"—something hallucinatory happens. I watch the line become a bridge suspended in air. And I am on it, running back and forth, which is my existential condition. (Kaufman 1998, p. 165)

Although Kaufman was familiar with Hebrew biblical poetry by women poets (several such poems appearing in the bilingual anthology adduced above), the fact that she wrote in English and published her books in the United States means she is more closely associated with the Jewish-American than the Hebrew-Israeli writing tradition (Koplowitz-Breier 2019). Her reading of biblical texts should thus be viewed as belonging to the midrashic-poetry tradition established by Jewish-American women as part of the Jewish feminist wave: "The last thirty years have seen a bold, rapidly accelerating renaissance of the form, as North American short story writers, poets, playwrights and novelists have returned to the biblical text to struggle with contemporary issues in Judaism" (Walton 2011, p. 116).

Some scholars suggest that the modern trend of rereading the Bible from a Jewish woman's perspective can be traced back to Rebecca Hyneman's poems about female biblical characters, published between 1846 and $1850 .{ }^{1}$ Others argue that, retaining a "traditional outlook," her writing continues to reflect a "convergence of American and Jewish gender roles" (Lichtenstein 1992, p. 66). In contrast to contemporary feminist midrashists/poets, she composed "poems in praise of biblical women, celebrating rather than questioning them, as modern poets would later begin to do" (Rosenfeld 2009).

Kaufman is not a direct heir of this early (non-feminist) midrashic movement. In fact, dating back to her early work, her biblical poetry was adopted as a model by later poets. As Enid Dame remarked in "Poetry and the Feminist Movement", “Later, I heard Shirley Kaufman read the stunning 'Déjà vu' ... These re-interpretive biblical poems had a powerful effect on me as a fledgling poet" (Dame 2002, p. 7).

1 Born in Pennsylvania in 1816 to Abraham Gumpertz, a Jewish-German storekeeper, and a Christian mother, Rebekah married Benjamin Hyneman, a jewelry peddler, in 1835, formally converting to Judaism in 1845 . Her religious poetry began to appear regularly in The Occident, a Jewish journal edited by Rev. Isaac Leeser of Philadelphia, cantor of Congregation Mikveh Israel. In 1853, a collection of her poetry, entitled The Leper and Other Poems was published by Leon Hyneman's publishing house. She also contributed secular poetry, short stories, novellas, and serial novels to The Masonic Mirror and Keystone, a newspaper edited by Leon Hyneman: http://www.jewish-history.com/Hyneman/hynemanbio.html. 
When asked whether she considered herself a feminist poet, Kaufman also recognized this dimension of her writing:

I don't like labels, but clearly I write with a woman's sensibility - and an increasing awareness of what has happened to us in a male dominated world.... And to the extent that I share a lot of my feelings with other women and try to do something about our empowerment, I guess you could say that I am a feminist poet. (Bloch 1998, p. 8)

In this sense, her work forms part of what Alicia Ostriker calls the "Unwritten Volume":

Women strive toward autonomous self-definition as women, which should be no surprise, since they have been defined by patriarchy for four thousand years. They write of the struggle against gendered muteness, gendered invisibility, and their own sense of being divided selves.... Finally, they write revisionist mythology, invading past tradition in order to change it. (Ostriker 1993, p. 101)

According to Ostriker, modern women poets engage in three, frequently overlapping, hermeneutics of biblical revisionism—suspicion, desire, and indeterminacy:

With the first of these we are ... quite familiar; sceptical critique is the feminist's stock in trade. Its opposite, the hermeneutic of desire-the discovery in a text of what we need to discover, the citing of what we love and wish to find sacred, the bending a text to our own will-is equally important for the woman writer... Lastly, the hermeneutic of indeterminacy depends on the recognition that, as the rabbis say, "there is always another interpretation." (Ostriker 1997a, pp. 165-66)

Although at first glance the three principles appear to be independent, they all in fact blend into one another in most of the poems discussed in this essay. I thus suggest that the "hermeneutics of indeterminacy" - which Ostriker (1993, pp. 66-67) herself regards as "most significant for the future"-already contain the other two, allowing other interpretations and/or ways of reading. Some are nevertheless more prominent than others.

In Ostriker's view, (female) re-readings of Scripture do not contravene the biblical text, the Jewish Sages asserting that God intended "all the meanings that He has made us capable of discovering." Female truths are thus present in this text as both sacred comedy and sacred tragedy (Ostriker 1997b, p. xiii). Revising the biblical text, they add new insights in direct continuation of the midrashic tradition. In support of this assertion, she quotes Gerald Bruns, who argues: "We take the texts in relation to ourselves, understanding ourselves in its light, even as our situation throws its light upon the text, allowing it to disclose itself differently, perhaps in unheard-of ways" (Ostriker 2003, p. 633).

This way of reading the Bible corresponds to Adrienne Rich's definition of "re-visioning" as an "act of looking back, of seeing with fresh eyes, of entering an old text from a new critical direction ... an act of survival.... And this drive to self-knowledge, for woman, is more than a search for identity: it is part of her refusal of the self-destructiveness of male-dominated society" (Rich 1972, p. 19). Kaufman follows Rich and Ostriker in empowering female biblical character by making use of her/their own words. Many of her poems address feminine aspects of relationships, family ties (especially mothers and daughters), growing old as a woman and writer, etc. As Lois Miller Bar-Yaacov observes, these themes also inform her midrashic pieces:

The same psychological insight and empathetic intuition which inform Kaufman's poems about her family have been the base of a whole series of poems about women in the Bible, practically a sub-genre in her poetry. ... Kaufman succeeds in endowing these shadowy "wives" with an innerness which the Bible does not provide. (Bar-Yaacov 2006)

While these biblical women occasionally speak in the biblical text (e.g., Rebecca) or even make us privy to their inmost thoughts, Kaufman addresses the "gaps" and omissions, adding her own perspective 
to the biblical story. In an introduction to an edition of Religion and Literature entitled "Turn it and Turn it": A Forum on Contemporary Midrash," Alicia Ostriker remarked: "Contemporary midrashim—and midrashists-commonly rejoice in the gaps, foreground the contradictions, and explore issues that are psychological, political, philosophical or spiritual in a broad sense rather than halakhic or religious" (Ostriker 2011, p. 113). Marge Piercy—a poet and midrashist of note-similarly observes:

Midrash is the entrance into the canon through the back door. In the patriarchal world of the texts, we miss the voices and ideas of women. So we put them back in.... We women who write midrashim are putting our truths into the ongoing oral Torah that is remade, reinterpreted, and added to generations after generation so that Judaism remains alive, and not a fossil or relic. (quoted in Schneider 2001, p. 64)

As this article hopes to demonstrate, Kaufman's biblical poetry engages primarily in a psychological and political interpretation of biblical women. Her poems evince little diachronic development in this regard. Amongst those reflecting the Israeli-Palestinian conflict, one that hints at the subject can already be found in her first book ("Rebecca" 1970). She alludes more explicitly to the subject in her 1984 book Claims ("Déjà Vu") and in "The Death of Rachel," published in 2000. As she herself observed, biblical women are her constant companions, letting her speak for and through them. On this basis, Kaufman's approach to reading the Bible can be analyzed as elaborating (on) its feminine characters via three devices: (a) Dramatic monologues, in which the woman speaks for herself ("Rebecca" and "Leah"); (b) a description of specific scenes that gives us a glimpse into the character's point of view ("His Wife", "Michal", "Abishag", "The Wife of Moses", "Yael", and "Job's Wife"); and (c) the interweaving of the biblical context into contemporary reality ("Déjà Vu" and "The Death of Rachel").

\section{Dramatic Monologues: Rebecca and Leah}

Four of Kaufman's ten poems dealing with feminine biblical characters relate to the matriarchs: Sarah, Rebecca, Leah, and Rachel. Only Rebecca and Leah speak, however, both addressing their spouses-Isaac (without mentioning his name) and Jacob. While "Rebecca" deals with a specific situation - her deception of Isaac so that he blesses Jacob instead of Esau in passing on the birthright-Leah speaks of her status as the "hated woman" in general. Kaufman's choice of the dramatic monologue in both cases may reflect a twentieth-century trend that "continued to be appropriated for the purposes of social critique and which was considered particularly well suited to the exploration of the issues of presentation and communication" (Byron 2003, p. 119). Enabling the speaker to articulate herself through diverse voices, the dramatic monologue gives marginalized characters the opportunity to speak, voicing the writer's views and ideas. While "Rebecca" and "Leah" are both peripheral figures, Rebecca is a far less common poetic subject than Leah-perhaps because due to her more assertive character (Govrin 2007, pp. 268-89).

Published in Kaufman's first book, The Floor Keeps Turning, "Rebecca" let us into the matriarch's thoughts and feelings (Kaufman 1970, p. 60). According to Genesis, she played a direct role in the deception:

Rebekah said to her son Jacob, "I overheard your father speaking to your brother Esau, saying, 'Bring me some game and prepare a dish for me to eat, that I may bless you, with the LORD's approval, before I die.' Now, my son, listen carefully as I instruct you. Go to the flock and fetch me two choice kids, and I will make of them a dish for your father, such as he likes. Then take it to your father to eat, in order that he may bless you before he dies." $(\text { Gen 27, 6-10) })^{2}$

While the biblical text depicts Rebecca's action and her dialogue with Jacob, making it clear that she is the driving force behind the ruse, in the two first stanzas in the poem Rebecca narrates this information

2 Biblical quotations follow the JPS (1985). 
herself. Kaufman portrays Rebecca as active vs. the more passive Isaac and Jacob. While Isaac waits for Esau to bring him the food he asked for, Jacob is "slow to move." No dialogue taking place between Rebecca and Jacob, Rebecca appears to have devised and initiated the scheme herself.

Genesis gives no indication of Rebecca's emotions when Jacob approaches Isaac. Exploiting this "gap," Kaufman articulates them explicitly in Rebecca's voice in the third and fourth stanzas:

It wasn't easy pacing inside my flesh while Isaac ate, sucking my breath between the cracks of my small teeth, hotness climbing over my face, the way I waited for him as a bride.

I listened still to water at the well. my arm uplifted to the jug.

The stress is depicted via physical attributes_-"pacing inside my flesh", "sucking my breath", and "hotness climbing over my face," Kaufman comparing it with another episode in Rebecca's life: The wait to meet Isaac. Rather than breaking once the blessing has been given, the tension "stays in my ears like cramps." Meant to give her relief, it brings her no comfort, Rebecca apparently anticipating the rivalry that will develop between Esau and Jacob.

Kaufman also addresses Rebecca's treatment of Isaac, whose blindness is the pivot around which the "plot" hinges. His lack of sight disturbs Rebecca, making her feel as though they are engaged in a "duplicity that sticks" - her use of Isaac's physical blindness to trick him. This sense is enhanced by the dual meaning of the verb "stick": Signifying "stabbing," it highlights her unease at being branded by the duplicity; denoting "cheating" in American slang, it questions the efficacy of the hoax: Can a blessing extracted via subterfuge fulfill its promise?

This question may be answered in the concluding lines. Here, Kaufman chooses to quote (with minor alterations) only part of the blessing: "Let peoples serve you, and nations bow to you" (Gen 27:29). This may hint at the problematic political fallout of the deception in today's world, following the State of Israel's occupation of the West Bank and taking control of Gaza in 1967. Kaufman herself opposing the Israeli occupation of the West Bank, the blessing implying that Jacob/Israel rules over other nations lodged itself in her ear as a relentless series of cramps rather than "ringing" therein. The repetition "Blessed, blessed" then takes on an ironic tone.

The defect in the scheme may also be reflected in Isaac's portrayal in the final stanza, in which he gives the impression of having chosen to "turn a blind eye," thereby undercutting the fraud:

Clumsy at noontime in his night,

he wiped his mouth and shook the light

outside him, touching the wrong one.

His fingers, delicate as leaves,

dropped in the false skin.

On this reading, Isaac knows that Jacob rather than Esau stands before him, deciding not to reveal his "insight." Despite his "clumsy" fingers, he shakes the "light outside him," knowing it to be a "false skin." The rhyme "night-light" hints at his awareness and decision to remain in night/blindness through to "noontime."

Hereby, Kaufman re-visions the biblical text, casting doubt on the ruse by giving us access to Rebecca's most intimate emotions and thoughts-along with her uneasiness at her part in the plot and its effect(iveness). Hinting that Isaac "sees" the trap for what it is, she also raises the specter of the contemporary political situation, suggesting that the blessing may in fact be a curse.

Published in From One Life to Another, "Leah" addresses Jacob (Kaufman 1979). Several other poets writing in Hebrew (e.g., Shimshon Meltzer, Anda Pinkerfeld Amir, and Yaakov Azriel) and English (e.g., Barbara Holender and Sherri Waas Shunfenthal) that take Leah as their subject are also 
composed as dramatic monologues. (Koplowitz-Breier 2010) This may be a (conscious or unconscious) response to the fact that Leah remains virtually speechless in the biblical text. Despite her matriarchal status, Leah is only given a voice twice in Genesis-when she names her sons and daughter, explaining the meaning of each name (Gen 29:32-35, 30:9-13, 17-21), and in a brief conversation with Rachel, her sister, over the mandrakes Reuben brings in from the field (Gen 30:14-15). Nowhere else does she speak aloud (or even move her lips) or express her thoughts. Jerry Rabow (Rabow 2014) thus calls her the "lost matriarch." The dramatic monologue gives the poet/Leah the opportunity to "pour her heart out," letting us know her deepest emotions and thoughts regarding her status as the "weakest link" in the ménage à trois.

As she laments her position, Leah coopts various unflattering descriptions to portray herself: An "obedient daughter or a dog", "the ugly one", "sag[ging] ... after each birth", "a stone, a shell your [Jacob's] foot rolls over/in the sand", sucked "empty and dull" by her sons' departure, and "raging." Hereby, she paints herself as unloved, jealous ("I watch you/every day as you watch her"), and in pain ("Why can't you look at me/in daylight, or take/my hand and press it/against your mouth?"). All she seeks is some attention from Jacob, rather than being treated as an object-her womb the receptacle for his children and an empty shell. Even their sexual intercourse is passionless. While each time seems to be a repetition of their wedding night_- "the one pushed into your bed/at night when you can't/tell the difference" — the sex is perfunctory and unceremonious: "I enter the water/as you enter me. Quick./Like insects doing it while/they fly." Even if the final two stanzas seem to suggest that Leah will "take her life" in her own hands, she is in fact too passive and obedient to act. The only way she can express her frustration is by "raging/against the stream."

Herein, Leah gives voice to the emotions the biblical text omits, venting her hurt and anger. Even while ostensibly addressing Jacob, her words appear primarily directed towards herself. Her status as the hated wife is exacerbated by her fertility. Leah is frustrated by the fact that her childbearing merely objectifies her in his eyes, Rachel remaining the (one with the) beautiful and desired figure. At the same time-and by the same token-her body has had its life sucked out of it, leaving it a shell. Leah's grievance may thus also derive from the fact that Jacob's objectification of her makes her think of herself in precisely the same way.

\section{Description of Specific Scenes: Wives and Spouses}

Wittingly or unwittingly, this group of Kaufman's biblical poems all relate to biblical wives or partners. Published in The Floor Keeps Turning, "His Wife" deals with Lot's wife, who, looking back while fleeing Sodom, became a pillar of salt (Kaufman 1970, p. 3). Ignoring Lot completely, Kaufman explores what made his wife disobey the divine command. As Frank Kearful observes in his close textual analysis: “Unable to name ishto, Shirley Kaufman's 'His Wife' ... indulges in fair-is-fair irony by making her husband equally nameless" (Kearful 2000, p. 256). At the other end of the spectrum, "Michal" — published in Gold Country_belies its title by devoting only nine out of its 31 lines to the "protagonist," seeking primarily to explain David's dancing on returning the ark to Jerusalem and the reason it perplexes Michal (Kaufman 1973). It thus commences with David's perspective: "That wife unsettles me. Michal/at her window exhales propriety/worries about appearances." The poet therefore appears to understand David better than his wife, who is more concerned about appearances than the ark's restoration to the Israelites.

Most of the poems, however, reflect the wife's perspective on the situation. "Abishag" elaborates the biblical story of Abishag the Shunammite, chosen as a beautiful virgin to warm David's bones in his old age (1 Kings 1-4) (Kaufman 1981, pp. 189-99). While Abishag does not speak in the poem, Kaufman makes us privy to her thoughts. While focusing on the theme of royal bed-warmer, as the poem develops Abishag is transformed from an object of the king and his servants' gaze into a subject with her own thoughts and an awareness of her power to mock. Zooming in on the biblical text, Kaufman invokes its specifics, the "familiar figures of David and Abishag, recognizable at a distance, becoming distorted on closer examination" (Stahlberg 2009, p. 131). 
The poem consists of four stanzas of eight lines, divided almost equally between the perspective of the king's servants (stanza 1), David (stanza 2), Abishag (stanza 3), and the king and Abishag (stanza 4). The first describes Abishag's mission, the servants being responsible, according to the biblical text, both for the idea of finding David a "bed-warmer" and for executing the plan. For them, she is an object rather than a human being: "To dangle around his neck,/send currents of fever/through his phlegmatic nerves, something/like rabbit fur, silky,/or maybe a goat-hair blanket/to tickle his chin." Abishag's "blanket effect" objectifies her even further.

The second stanza heightens this impression, David appearing to treat her as a garment or road-map. Despite her directions, however, he cannot find his way: "He spreads her out/like a road-map, trying/to find his way from one point/to another, unable." This incapacity to go and come highlights his impotence in her company. Here, Kaufman introduces an additional factor into the biblical phrase "but the king did not know her," intimating David's dysfunction. Abishag's passivity is thus paralleled by his.

Abishag's own thoughts, as manifested in the third stanza, reveal the bed-warmer to be an ice maiden. What she really would like to do is dissolve the king and make him vanish: "She thinks if she pinches/his hand it will turn to powder." The king makes her imagine an old bird: "She feels his thin claws, his wings/spread over her like arms, not bones/but feathers ready to fall." The "bird" metaphor broadens the king's description in the second stanza as "a lost bird pecking in winter." Birds are usually connected with freedom and the ability to see everything from above. In this case, however, the opposite is true, the king being impotent, unable "to find his way from one point to another," the "feathers ready to fall" from his wings. The metaphor thus seems to mock the old king (Koplowitz-Breier 2018, pp. 26-27).

At the end of the stanza, Abishag responds to the king cruelly, knowing that her beautiful feminine body is a constant reminder of his current state, contrasting sharply with his glorious past as a womanizer. In the final stanza, Kaufman explicitly portrays Abishag in sexual terms (her breasts, her mouth slightly open, her hair spilling everywhere) in order to highlight the fact that the royal virility has disappeared. Rather than a miserable village girl, Kaufman's Abishag is thus a woman who, while recognizing her function as a heating device-an object-is also aware of her power over the poor old king, forming a constant reminder of his lost past.

"Zipporah" takes us to the only occasion on which the biblical text fleshes out Moses' wife somewhat-namely, her circumcision of their son to save him (or Moses?) from God's wrath. (Kaufman 1990, p. 69; 1993, p. 9) Kaufman nevertheless omits Zipporah's own words at the end of the biblical verse: "You are truly a bridegroom of blood to me!" (Exod 4:25). The text being amenable to various interpretations, Kaufman maintains its abstrusities (Cohen 2005, pp. 120-26). It also provides the opportunity for discussing Zipporah's relations with Moses, however, being the only time we see them together. The next time we hear of Zipporah is in Exodus 18. While her father Jethro brings her and her sons back to Moses, however, on this occasion they remain unconnected: "We are not told why Moses had sent Zipporah home, but the fact that he doesn't even greet her upon her return (he speaks only with Jethro) seems to indicate that this relationship has little meaning to him. He is now, as it were, married to God" (Pardes 1992, p. 97).

Kaufman adduces the marital estrangement in the very first line: "Something went wrong." Not privy to the voices Moses hears, Zipporah can only do as she is told: Pack. The second stanza treats her circumcision of the boy. Here, Kaufman follows the traditional exegesis that Moses was supposed to undertake this task as his father:

\footnotetext{
It wasn't her job,

this blood on her fingers,

this cut flesh, red love-bite

in the sand.
}

While this suggests that Zipporah is motivated by love ("red love-bite"), in the following stanza the gap between her and Moses deepens: "The desert widens between them/like an endless argument." 
Again adopting a traditional line of exegesis (taken by Ibn Ezra, for example), Kaufman links the circumcision with the blood on the doors that protected the Israelites during the plague of the firstborn: "Slice of the covenant: blood/on the doors" (Hays 2007, pp. 39-54). Circumcision—a slice of flesh-is a pledge of commitment to God, who protects the foreskinless just as the firstborn.

In the final stanza, the couple's relationship has completely broken down, Moses having chosen God: "He's off to his mountain." She remains alone, nothing existing for her to be remembered by. Even her saving Moses/their son from God's retribution is forgotten: "She'll lose/what she saves,/fall out of the future/thankless ... " As in the biblical text ("Jethro, Moses' father-in-law, brought Moses' sons and wife to him in the wilderness" [Exod 18:5]; "I, your father-in-law Jethro, am coming to you, with your wife and her two sons" [Exod 18:6]), however, the boys now became hers rather than Moses'. Zipporah "holding the small face/unfathered anyway, crying/between her hands," the son no longer belongs to his father but to his holding mother.

Kaufman's Zipporah matches the biblical description of her as becoming an increasingly insignificant factor. Even when Miriam refers to the Cushite woman Moses took as his wife (Num 12:1), this may not be Zipporah, not being identified by name (Serino 2016, pp. 153-77). At the end of the poem, Zipporah loses Moses to God for good, the voice her husband "went on listening to," which "she couldn't hear" in the first stanza, bearing him away "to his mountain," leaving her alone with "nothing to lean on/but her own arms." This process of identity-loss becomes stronger in the second version of the poem, which it is retitled as "The Wife of Moses." Now nameless and husbandless, Kaufman depicts her transformation from an affectionate wife who lovingly circumcises her son with her own hands to a deserted, unmemorable aguna.

Another of the group of poems dealing with wives is "Yael" (Kaufman 2000, p. 157; 2003, p. 113). Although the biblical text tells us that Yael was the "wife of Heber" (Judg 4:17), Kaufman does not make this explicit in the poem-perhaps because she focuses on Yael's actions and thoughts before Sisera is killed and the fact that her deeds are disconnected from her husband. The first two stanzas relate to Yael as Sisera approaches her tent. The first paints her in angelic terms, the tent's open flaps serving as her wings: "She must be an angel, waiting outside/with the tent flaps open./ ... He enters the shelter of her wings." This recalls Micah Joseph Lebensohn's poem "Yael and Sisera" (1851), in which Sisera initially calls Yael "Angel from heaven" and then "Angel of death." For Kaufman, however, Yael is always a positive celestial figure.

The second stanza continues to depict Yael's actions. The first two lines closely follow the biblical text: Yael gives Sisera milk to drink, covering him with a blanket. While some biblical commentators believe Sisera and Yael had no sexual relations, most exegetes, both ancient and modern, maintain that Judg 4:17-22 hints at Yael's seduction of the general, leading to intercourse (Niditch 1999, pp. 305-15; Assis 2004, pp. 82-90; Shemesh 2006, pp. 159-77). Although Kaufman appears to follow this line

Reckless, she lies down beside his fever,

His breath burns in her cool mouth.

His stunned hands harden

against her body

when read in light of the first stanza, Yael may only be seeking to sooth the "half-dead" warrior and bring down his fever.

The final stanza takes us back to the previous summer. Here, Yael is contrasted with the men: While she shepherds the flock, they "sharpen their sticks," getting ready for battle. Yael thus begins life as a pastoral figure, becoming caught up in a violent masculine affair against her will: "The sweet/brutality she's servant to." Knowing "what she has to do" means acting against herself. Despite "angelically" extending assistance to Sisera, she is a woman. A lackey in men's hands, she is thus condemned to kill the general. Rather than part of her wiles, her soothing is an expression of tenderness. Elaborating the biblical phrase "stealthily" (Judg 4:19), Kaufman explains that her acts are a consequence of her status within patriarchal society. 
"Job's Wife" was published twice. In Dreaming the Actual: Contemporary Fiction and Poetry by Israeli Women Writers, the poem is dated to 1996, the final line in this version reading: "at the rancid sky" (Glazer 2000, p. 371). In Threshold, this is replaced with "at the unrelenting sky" (Kaufman 2003, p. 114). Although seemingly minor, the alteration is of some import, as I shall discuss below.

The biblical text tells us little more than that Job had a wife: "His wife said to him, 'You still keep your integrity! Blaspheme God and die!' But he said to her, "You talk as any shameless woman might talk! Should we accept only good from God and not accept evil?" For all that, Job said nothing sinful" (Job 2:9-10).

The nameless biblical wife-whom the apocryphal Testament of Job identifies as Siti(do)s-plays no real role in her husband's story (van der Horst 1989, pp. 93-116; Scholtz 2013, pp. 819-39). Only appearing in the prose frame story, she "prefigures or perhaps even generates the impatience of the dialogues" (Pardes 1992, p. 147). Those exegetes who pay her attention dispute her character and place in Job's story, rarely if ever addressing her feelings (Magdalene 2006, p. 214). The dialogue between Job and his wife is very short, she appearing to be perplexed by his silence in front of God, seeming to think that it would be better if he articulated his agony, cursed God, and died rather than suffer quietly. Job disagrees, telling her she is a foolish woman, God's evil deeds requiring acceptance in the same way as His good ones.

Kaufman depicts this episode from Job's wife's perspective. The first line adduces the way she feels about his suffering: "She has to pity him after what happened." The second stanza presents her side of the story, Job being so immersed in his own agony that she is left aside. She debates the right moment to approach Job, hoping that he will understand that all the family has been affected and should be taken into consideration: "surely he'll speak/for her too, three daughters, seven sons,/aren't they in this together?" She appears to assume that Job will speak with God.

In the third stanza, feeling she has nothing more to lose, she makes her move: "She begs him to damn God and die." The word "begs" exposes the depth of her grief: In "damning" God on behalf of both of them, she will die alongside her husband.

The fourth stanza conveys her emotions towards Job and their situation: "He's all that's left, beyond what they/used to be for each other, abuse/or solace." "In sickness and in health", their relationship is all that is left to them. Even before their troubles began, however, it had already become rocky, dangling between "abuse or solace."

Kaufman alters the biblical account of Job's response to his wife's words, making him more abusive and omitting his explanation about welcoming evil as (well as) good. She reacts by staring at the sky. In the 1996 version of the poem, Kaufman describes this expanse (representing God) as "rancid," hinting at Job's wife's anger and resentment at God (and her husband). In the 2003 version, it becomes "unrelenting," adding a measure of desperation to the mix. While all her hope has disappeared, Kaufman has given life to this marginal figure.

In revisioning these marginal characters in the biblical text (even Yael only being given seven verses), Kaufman makes us revisit them via Ostriker's hermeneutics of indeterminacy and desire. In the first, Kaufman reads the biblical women's figures afresh; in the second, she highlights their feminine perspective, enhancing their emotions and relations with their male partners.

\section{Interweaving the Biblical Context into Contemporary Reality: Sarah and Rachel}

The third group of poems consists of two dealing with Sarah and Rachel. In both, Kaufman contemporizes the matriarchs. As the title of the first, "Déjà Vu," intimates, Sarah and Hagar represent the Israeli-Palestinian conflict as a new incarnation of the conflict between their sons, Isaac and Ishmael. The poem was first published in Claims, subsequently being printed in several other places with some alterations (Kaufman 1984, pp. 29-31; 1996, pp. 111-12; Glazer 2000, pp. 365-66). It opens with a concern shared by virtually every mother: "Whatever they wanted for their sons/will be wanted forever." Out of this nameless collective, Sarah and Hagar emerge in the second stanza, located on the Temple Mount—a flash point in the Israel-Palestinian/Jewish-Muslim dispute. 
Sacred to both religions, this is both "the rock/where Isaac was cut free" (Jewish tradition holding that Abraham sacrificed Isaac on Mount Moriah) and "the place where Mohammed flew up to heaven." Sarah shows tourists around the Dome of the Rock, Hagar kneeling there in prayer. While they appear to have met by accident- “They bump into each other at the door,/the dark still heavy on their backs/like the future always coming after them"- the encounter is fraught with history, Sarah having forced Abraham to banish Hagar and Ishmael. The tension finds expression in silence, however: Sarah "wants to find out ... but is afraid to ask," Hagar's lips making "a crooked seam/over her accusations." Just as Sarah and Hagar never speak in the biblical account, so the situation has changed little thousands of years later (Pardes 1992, p. 66).

In the fourth stanza, contemporary reality takes the form of the depiction of the world as flat. This metaphor has two aspects. The ancients believing the world to be flat, the biblical Hagar and Sarah might have thought that "if they move to the edge/they're sure to fall over." Their emotions are also "on (the) edge," making them capable only of "follow[ing] their own feet/the way they came." Just as the past cannot be changed, neither can the present, the two of them thus "walk[ing] out of each other's lives/like the last time, silent."

As though to underscore the merging of time, the second part of stanza commences: "Jet planes fly over their heads." Representing the present, this idea is set against the miraculous aspects of the biblical story: "the angels of god and the bright/miracles of birth and water." The reference to the fact that "the boys are gone" at the end of the stanza then draws us back into the present. Despite the two sons long being dead, the conflict between the two nations continues (Ostriker 2016, p. 121). The final two stanzas remain in the present day. The sixth depicts Sarah, opening with a "weather report":

The air ticks slowly. It's August

and the heat is sick of itself

waiting all summer for rain.

The relationship between the two parties is strained. In her "cool villa," Sarah "keeps her eyes on the pot/so it won't boil over"- the conflict always on the brink of igniting. Things are tense not only because of the Israeli-Arab clash, however, but also due to everyday Israeli life, with its "common corruptions." Sarah tells "him" (the domestic description intimating this to be Abraham) whom she has met. Even the domestic sphere is taut, a desert separating the couple. Recalling Hagar's exile against Abraham's wishes (Gen 21:10-12), Sarah's command "Cast out that slave-woman and her son" appears to have opened up a gulf between herself and her husband. In the second version of the poem (Roots in the Air), however, Kaufman alters the desert metaphor ("Guess who I met she says, talking/across the desert"), exchanging it for a more neutral one: "Guess who I met she says, dipping into the hummus." The tense atmosphere between the couple thus seems to turn more habitual, intensifying perhaps the contrast between Sarah's domesticity and Hagar's depiction in the last stanza.

In contrast to Sarah's "cool villa," Hagar shops in the market, pondering her situation. While her fate seems to be worse than Sarah's, she is in good spirits: "I got what I wanted from the old man." She thus appears content with her lot. Despite the strain between the two mothers, apparent from the beginning of the poem, Hagar accepts her condition. Kaufman nevertheless implicitly judges their different ways of life: while Sarah remains "cool" in her villa, Hagar "climbs the dusty path home."

In light of the fact that she treats the "flight in the wilderness" as "a morning stroll," Hagar appears to imply that, in comparison with her present circumstances, her banishment to the desert was a "walk in the park." The antithesis between the two biblical characters in present time, reinforced by their contrary states (standing/kneeling, guiding/praying, cool home/hot market and dusty path) conveys the ongoing nature of the Israeli-Arab conflict. The fact that the only thing they share is silence (stanza 3) gives little hope for its resolution.

"The Death of Rachel," first published in Stand Magazine in 2000, again blends the biblical period and the present, Rachel the matriarch being both dead and alive (Kaufman 2000, p. 72; 2003, p. 112): 
All day she stirs the soup while the tourists park their cars on the side of the road to visit her tomb. Soldiers stand guard. Barren women sway in their scarves and pray for child.

Stirring the soup represents the way she spent her life, her daily habit continuing as tourists, soldiers, infertile women coming to pray visit her tomb. The soup itself consists of "bitter lumps/from the dry river beds," the rocks that form her existential vicissitudes: Her bitterness over being barren for so long and death during childbirth. It represents her emotions, which, if she cannot control them, will overpower her: "She keeps her eyes/on the pot so it won't boil over." Significantly, "Déjà vu" uses the precisely the same metaphor to describe Sarah. In both cases, the boiling pot symbolizes Rachel/Sarah's emotional state and the contemporary political situation. While the political Israeli-Arab tension is explicitly referenced by the dichotomy of Sarah-Hagar relationship in "Déjà Vu", however, it is only hinted at by the presence of the soldiers guarding the grave in "The Death of Rachel." The second and third stanzas revert to the biblical period. The second portrays Rachel's theft of her father's idols-an abstruse scene. The biblical text does not explain the reason for the act, even Rachel's words to Laban being equivocal:

By leaving it open to our conjecture, the narrator enables us to interpret "the way of women" as a reference to Rachel's menstruation as well as to the fact the she is deceiving her father.... For Rachel's appeal to the "way of women" puts in her mouth a condemnation of her own sex, by combining in the same expression a reference to woman's alleged somatic impurity and moral inferiority. (Fuchs 1988, pp. 79-80)

Kaufman treats the phrase in literary form, however, Rachel explicitly stating: "the slit moon under her skirt/spilled blood and she couldn't rise." Her truthfulness is nonetheless questioned at the beginning of the fourth stanza: "She's run out of lies." The biblical text only attributes two falsehoods to her: (indirectly) failing to reveal her father's deceit on the wedding night and hiding the idols from her father by claiming that she is unclean due to her menstrual cycle. The second lie puts her at risk of death, Jacob—unaware of her culpability, swearing: "But anyone with whom you find your gods shall not remain alive!" (Gen 31:32). Although the curse is directed against the person whom Laban discovers in possession of the idols, many commentators link it with Jephthah's oath in Judges 11 (Zierler 2004, pp. 1-14).

The final stanza describes Rachel's death:

She has been ready for a long time

listening to the calm of the desert

between her pains.

She strains till the last one in her

forces his dark head out.

Although Rachel dies giving birth to Benjamin, Kaufman portrays her as having been ready for the event "for a long time" due to the pain that has been plaguing her. The hard labor the biblical text describes is also reflected in the stanza. Her death is adduced by the resumption of the stirring motion with which the poem commences: "She stirs the dust into dust." This phrase (Gen 3:19)—part of the Jewish burial ceremony-associates Rachel's emotions with her death, the stirring linking Rachel with visitors to her tomb. From the outset of the poem, she thus integrates both life and death, the soup-a combination of liquidity and dryness ("bitter lumps/from the dry river bed")—being formed of the same ingredients. It may also be connected with the tears of the praying women and Rachel's own:

A cry is heard in Ramah-wailing, bitter weeping-Rachel weeping for her children.

She refuses to be comforted for her children, who are gone. Thus said the LORD: Restrain 
your voice from weeping, your eyes from shedding tears; For there is a reward for your labor-declares the LORD: They shall return from the enemy's land. And there is hope for your future-declares the LORD: Your children shall return to their country. (Jer 31:15-17)

The portrayal of the tomb appears to exemplify the "returning sons/daughters." The depiction of the soldiers guarding the site and the metaphor of reality as a "pot" that is about to "boil over" add a political angle to the poem, however, calling into question the very essence of the return: is this really the coming back of the "children ... to their own border"? The fact that Rachel's death is associated with giving birth after having being barren for so many years-and perhaps also the possibility of visiting the tomb after so many years-nevertheless gives hope to infertile women.

Rachel's commemoration is thus essentially oxymoronic, representing death and birth, barrenness and fertility. This is also clear from the depiction of the contemporary tomb, which contains three elements: The tourists (who symbolize its cultural aspect), the soldiers (who embody the fragile political state, undermining the belief that Jeremiah's prophecy has in fact been fulfilled), and the barren women who pray for children (its oxymoronic essence). In elaborating (on) Rachel's death according to the biblical narrative and her present-day tomb, Kaufman adds a contemporary aspect to the biblical text. By linking Rachel's lies with her death and viewing the tomb and Rachel's story as oxymoronic, she calls Rachel's status as an iconic cultural matriarch and her tomb as a cultural center into question.

In both these poems, the female biblical figure serves Kaufman as a tool for conveying a political message. In this "revisionist mythmaking" the figure or tale is "appropriated for altered ends, the old vessel filled with new wine, initially satisfying the thirst of the individual poet but ultimately making cultural change possible" (Ostriker 1982, p. 72). As Monica Osborne observes in her article on Alicia Ostriker and Marge Piercy, Kaufman reads the biblical text midrashically here:

Midrash - an ancient manner of investigating and questioning sacred texts—for Jewish women poets is a method that allows them to creatively examine biblical texts and to pursue new significance in them. Feminist midrashic poetry, then, cultivates a literal reading of the female self into the text through radically reimagining its dimensions and often-though not always-reworking traditional poetic structures. (Osborne 2006, p. 78)

Hence, Kaufman's midrashic poetry is making the ancient biblical texts relevant by hinting that it contains the roots of contemporary times and conflicts.

In her biblical poems, Kaufman seeks to provide biblical women with a "room of their own," rewriting their stories as recounted in the biblical narrative via several literary devices. On some occasions, she highlights almost anonymous wives. In "His Wife" (Lot's wife), "Zipporah"/"The Wife of Moses", "Abishag", and "Job's Wife", the biblical women express their thoughts, (re)telling the biblical narrative from their (female) perspective. According to the biblical accounts, all four women undergo painful experiences in relation to their spouse. Lot's wife flees Sodom with him, but, looking back in contravention of God's command, turns into a pillar of salt. Zipporah circumcises her son to save him/her husband, later being left as an aguna. Abishag plays the role of a "heating device" for King David, and Job's wife, suffering the loss of their children, cannot comprehend why he does not rail at God.

All thus have things to say but no voice to articulate them within the biblical account. Letting us in on their story and perspective, Kaufman gives them (an after)life. While the matriarchs appear to occupy an important space in the biblical plot, a close reading of the text reveals "another story": They are virtually mute. Although addressing different figures, both "Rebecca" and "Leah" are dramatic monologues. Rebecca explains why she deceives Isaac into giving the blessing to Jacob instead of Esau, a political angle being introduced into the story. Leah speaks to her status as "hated wife" in comparison with her beloved sister, seeming to regard herself as an object—perhaps because this is how Jacob treats her. In these poems, an "undertone" of criticism of biblical patriarchalism underlies the women's emotions and thoughts- the consequences of the blessing and a view of women as breeding 
machines. In "Déjà Vu" and "Rachel's Death," on the other hand, Kaufman contemporizes the biblical story, using it as a vehicle for political-midrashic purposes.

In all her poems on biblical women, Kaufman thus fleshes them out and portrays them through contemporary lenses-creating new ribboni midrashim which, according to Ari Elon, differ from the old rabbani midrashim in their individuality and cultural stance towards the biblical text (Elon 1996, p. 36; Selinger 2011, p. 137). These biblical "afterlives" are a response to Jewish tradition, from which women have long been excluded (Stahlberg 2008). In "Roots in the Air," Kaufman observes: "Call it a Jewish woman's life, because in recent years, as my interest in gender studies and friendship with feminist writers has grown, so has my awareness of and anger at the attitude toward women and women's bodies in Jewish tradition and Israeli politics" (Kaufman 1998, p. 165). Although this essay suggests that Kaufman only changed her views in the 1990s, her re-writing—or "re-visioning"—of biblical women characters is already evident in her first book. She thus forms part of the growing Jewish feminist trend towards discovering a new way of approaching the Bible and Jewish texts. The various forms in which Kaufman re-writes the feminine biblical characters exemplify the contemporary wave of Jewish-American women poets and scholars and their endeavor to find their own niche on the Jewish bookshelf. In Kaufman's own conceptualization, this is her way of "coming to terms with the past" and the exclusion of "women's bodies" from Jewish tradition, giving biblical women a voice and "afterlife."

Funding: This research received no external funding.

Conflicts of Interest: The author declares no conflict of interest

\section{References}

Assis, Elie. 2004. The Choice to Serve God and Assist his People: Rahab and Yael. Biblica 85: 82-90.

Bar-Yaacov, Lois Miller. 2006. Shirley Kaufman. Jewish Women: A Comprehensive Historical Encyclopedia. Available online: https://jwa.org/encyclopedia/article/kaufman-shirley (accessed on 20 August 2019).

Bloch, Chana. 1998. The Bridge that I Live on: Talking with Shirley Kaufman. Poetry Flash 279: 4-10.

Byron, Glennis. 2003. Dramatic Monologue. London/New York: Routledge.

Cohen, Jeffery M. 2005. Hatan Damim-The Bridegroom of Blood. Jewish Bible Quarterly 33: 120-26.

Dame, Enid. 2002. Poetry and the Feminist Movement. Bridges 9: 6-8.

Elon, Ari. 1996. From Jerusalem to the Edge of Heaven. Translated by Tikva Frymer-Kensky. Philadelphia: JPS.

Fuchs, Esther. 1988. For I Have the Way of Women': Deception, Gender, and Ideology in Biblical Narrative. Semeia 42: 68-83.

Glazer, Miriyam. 2000. Dreaming the Actual: Contemporary Fiction and Poetry by Israeli Women Writers. Albany: SUNY Press.

Govrin, Nurit. 2007. Family Drama in the Life of Isaac and Rebecca: The Great Complexity of Relations and Parenthood. Kivunim Hadashim 15: 268-89. (In Hebrew).

Hays, Christopher B. 2007. Lest Ye Perish in the Way: Ritual and Kinship in Exodus 4:24-26. Hebrew Studies 48: 39-54. [CrossRef]

Kaufman, Shirley. 1970. The Floor Keeps Turning. Pittsburgh: University of Pittsburgh Press.

Kaufman, Shirley. 1973. Gold Country. Pittsburgh: University of Pittsburgh Press.

Kaufman, Shirley. 1979. From One Life to Another. Pittsburgh: University of Pittsburgh Press.

Kaufman, Shirley. 1981. Abishag. The Iowa Review 12: 198-99. [CrossRef]

Kaufman, Shirley. 1984. Claims. New York: Sheep Meadow Press.

Kaufman, Shirley. 1990. Zipporah. Tikkun 5: 69.

Kaufman, Shirley. 1993. Rivers of Salt. Port Townsend: Copper Canyon Press.

Kaufman, Shirley. 1996. Roots in the Air. Port Townsend: Copper Canyon Press.

Kaufman, Shirley. 1997. Here and There: The Use of Place in Contemporary Poetry. In A Field Guide to Contemporary Poetry and Poetics. Edited by Stuart Friebert, David Walker and David Young. Oberlin: Oberlin College Press, pp. 206-22.

Kaufman, Shirley. 1998. Roots in the Air. Judaism 47: 161-68. 
Kaufman, Shirley. 2000. Job's Wife. In Dreaming the Actual: Contemporary Fiction and Poetry by Israeli Women Writers. Edited by Miriyam Glazer. Albany: SUNY Press, pp. 365-66.

Kaufman, Shirley. 2003. Threshold. Port Townsend: Copper Canyon Press.

Kaufman, Shirley, Galit Hasan-Rokem, and Tamar S. Hess. 1999. Introduction. In The Defiant Muse: Hebrew Feminist Poems from Antiquity to the Present-A Bilingual Anthology. Edited by Shirley Kaufman, Galit Hasan-Rokem and Tamar S. Hess. New York: Feminist Press at the City of New York, pp. 1-29.

Kearful, Frank J. 2000. Shirley Kaufman's Art of Turning. In The Mechanics of the Mirage Postwar American Poetry. Edited by Michel Delville and Christine Pagnoulle. Liège: Université de Liège Press, pp. 253-75.

Koplowitz-Breier, Anat. 2010. Giving Voice to a Matriarch: Leah's Voice in Modern Israeli Dramatic Monologues. Women in Judaism. Available online: http://wjudaism.library.utoronto.ca/index.php/wjudaism/article/view/ 19252/15981 (accessed on 15 August 2017).

Koplowitz-Breier, Anat. 2018. The Power of Words: The Biblical Abishag in Contemporary American Jewish Women's Poetry. Studies in American Jewish Literature 37: 21-36. [CrossRef]

Koplowitz-Breier, Anat. 2019. Going nowhere: Movement and dislocation in Shirley Kaufman's poetry. Textual Practice. [CrossRef]

Lichtenstein, Diane. 1992. Writing Their Nations: The Tradition of Nineteenth-Century American Jewish Women Writers. Indianapolis: Indiana University Press.

Magdalene, F. Rachel. 2006. Job's Wife as a Hero: A Feminist-Forensic Reading of the Book of Job. Biblical Interpretation 14: 209-58. [CrossRef]

Niditch, Susan. 1999. Eroticism and Death in the Tale of Jael. In Women in the Hebrew Bible: A Reader. Edited by Alice Bach. New York/London: Routledge, pp. 305-15.

Osborne, Monica. 2006. And What if I Say the Purposes Have Not Yet Been All Revealed?: Searching for Psyche and Reimagining God in the Poetry of Alicia Ostriker and Marge Piercy. Studies in American Jewish Literature 25: 77-84.

Ostriker, Alicia Suskin. 1982. The Thieves of Language: Women Poets and Revisionist Mythmaking. Signs 8: 68-90. [CrossRef]

Ostriker, Alicia Suskin. 1993. Feminist Revision and the Bible: The Unwritten Volume. Oxford: Blackwell.

Ostriker, Alicia Suskin. 1997a. A Triple Hermeneutic: Scripture and Revisionist Women's Poetry. In A Feminist Companion to Reading the Bible. Edited by Athalya Brenner and Carole Fontaine. Sheffield: Sheffield Academic Press, pp. 164-89.

Ostriker, Alicia Suskin. 1997b. The Nakedness of the Fathers: Biblical Visions and Revisions. New Brunswick: Rutgers University Press.

Ostriker, Alicia Suskin. 2003. Whither Exodus: Movies as Midrash. Michigan Quarterly Review 42: 139-50. Available online: https:/quod.lib.umich.edu/cgi/t/text/text-idx?cc=mqr;c=mqr;c=mqrarchive;idno=act2080. 0042.118;g=mqrg;rgn=main; view=text;xc=1 (accessed on 3 April 2019).

Ostriker, Alicia Suskin. 2011. Introduction. Religion and Literature 43: 112-15.

Ostriker, Alicia Suskin. 2016. The Face of the Other: Sarah-Hagar Then and Now (Genesis 16, 21). In Reading Genesis: Beginnings. Edited by Beth Kissileff. London/New York: Bloomsbury, pp. 117-30.

Pardes, Ilana. 1992. Countertraditions in the Bible: A Feminist Approach. Cambridge: Harvard University Press.

Rabow, Jerry. 2014. The Lost Matriarch: Finding Leah in the Bible and Midrash. Philadelphia: JPS.

Rich, Adrienne. 1972. When We Dead Awaken: Writing as Re-Vision. College English 34: 18-30. [CrossRef]

Rosenfeld, Jessica. 2009. Poetry in the United States. In Jewish Women: A Comprehensive Historical Encyclopedia. Available online: https://jwa.org/encyclopedia/article/poetry-in-united-states (accessed on 28 July 2019).

Schneider, Steven P. 2001. Poetry, Midrash, and Feminism. Tikkun 16: 61-64.

Scholtz, Roger. 2013. I Had Heard of You ... But Now My Eye Sees You: Re-Visioning Job's Wife. Old Testament Essays 26: 819-39.

Selinger, Eric Murphy. 2011. Midrashic Poetry and Ribboni Poetics (With Special Reference to the Work of Joy Ladin and Peter Cole). Religion and Literature 43: 135-44.

Serino, Ron M. 2016. A Sign in the Dark: Moses's Chushite Wife and Boundary Setting in the Book of Numbers. Biblical Interpretation 24: 153-77. [CrossRef]

Shaked, Gershon. 2004. Modern Midrash: The Biblical Canon and Modern Literature. AJS Review 28: 43-62. [CrossRef] 
Shemesh, Yael. 2006. Yet He Committed no Act of Sin with Me, to Defile and Shame Me (Judith 13:16): The Narrative of Judith as a Corrective to the Narrative of Yael and Sisera. Shnaton 16: 159-77. (In Hebrew). Stahlberg, Lesleigh Cushing. 2008. Sustaining Fictions: Intertextuality, Midrash, Translation, and Literary Afterlife of the Bible. New York: T\&T Clark.

Stahlberg, Lesleigh Cushing. 2009. From Biblical Blanket to Post-biblical Blank Slate: The Lives and Times of Abishag the Shunammite. In From the Margins 1: Women of the Hebrew Bible and Their Afterlives. Edited by Peter S. Hawkins and Lesleigh Cushing Stahlberg. Sheffield: Sheffield Phoenix, pp. 122-40.

van der Horst, Pieter W. 1989. Images of Women in the Testament of Job. In Studies on the Testament of Job. Edited by Michael Knibb and Pieter van der Host. Cambridge: Cambridge University Press, pp. 93-116.

Walton, Rivkah M. 2011. Lilith's Daughters, Miriam's Chorus: Two Decades of Feminist Midrash. Religion $\mathcal{E}$ Literature 43: 115-27.

Zierler, Wendy I. 2004. And Rachel Stole the Idols: The Emergence of Modern Hebrew Women's Writing. Detroit: Wayne State University Press.

(C) 2019 by the author. Licensee MDPI, Basel, Switzerland. This article is an open access article distributed under the terms and conditions of the Creative Commons Attribution (CC BY) license (http://creativecommons.org/licenses/by/4.0/). 